\title{
Public Sector Deficits and Private Investment: A Test of the Crowding-out Hypothesis in Pakistan's Manufacturing Industry
}

\author{
ROBERT E. LOONEY
}

The purpose of the analysis below is to assess whether this public sector crowding out of investment in manufacturing has been a major factor affecting the pattern of private capital formation in that sector. The results of modified Granger Causality test suggest that expanded public investment in infrastructure has not played an important role in stimulating private investment in industry. If anything, it appears that private investment has stimulated a follow-on expansion in infrastructure. Instead of crowding in (i.e., a positive feedback effect) additional private investment, infrastructure investment appears to have led to larger deficits and domestic borrowing. In turn, these financial developments have dampened the flows of private capital into the important large-scale manufacturing sector.

On the other hand, financial crowding-out of private investment in large-scale manufacturing is a distinct possibility; but it may not be a simple, straight-forward process. The results obtained also suggest that private investment in large-scale manufacturing has suffered from real crowding-out associated with the government's noninfrastructural investment programme. Finally, it should be noted that neither financial nor real crowding-out seems to occur in other areas of private investment. Clearly, further research should be undertaken to determine why the large-scale manufacturing sector is unique in this regard.

\section{INTRODUCTION}

An important aspect of Pakistan's post-1988 stabilisation programmes has been the attention given to supply-side policies. The privatisation programme and the additional steps taken to liberalise domestic economical activities are key elements in the authorities' strategy to enhance the supply side of the economy. Expanded privatisation is accompanied by the opening of new activities (such as utilities assurance) to the private sector, further simplification of the investment regime, and removal of the remaining price distortions.

In addition, the authorities hoped that private investors would respond along

Robert E. Looney is Professor of National Security Affairs, Naval Postgraduate School, Monterey, California, USA.

Author's Note: The author is thankful to an anonymous referee of this journal for valuable comments on the earlier drafts. The author alone is responsible for any errors or omissions. 
the lines originally suggested by Hirschman (1958), taking advantage of the costreducing effects of infrastructure. Through this mechanism, public investment was to assume a leading role in financing expanded capital formation in productive investment, specially manufacturing.

However, the patterns of public and private investment have been rather paradoxical. That is, contrary to the development model led by 'unbalanced infrastructure' [Looney and Frederiksen (1981)] as postulated by Hirschman, several recent studies have found that public investment has played a rather passive role in stimulating follow-on private investment [Looney (1992, 1992a, 1994); Looney and Winterford (1992)]. Specifically, public facilities appear to have largely expanded in response to the needs created by expanded private investment in manufacturing, rather than strongly initiating the capital formation process.

Clearly, if the economy is to sustain high rates of overall growth in the future, the government must find ways of encouraging the private sector to play a more active role. Does this mean a shift away from infrastructure and towards other programmes which are more effective in encouraging private investment? Has the failure of infrastructure-led growth been due to a general unwillingness of the private sector to invest (despite the incentives created by infrastructure)? Or, has the expanded infrastructure investment created an offsetting set of factors associated with 'crowding out' or preemption of investment funds (or driving up borrowing rates), thus discouraging private investment?

The purpose of the analysis below is to assess whether this public sector crowding-out of investment in manufacturing has been a major factor affecting the pattern of private capital formation in that sector. Has crowding-out occurred? If so, was the crowding-out financial or real? Was crowding-out associated with public sector fiscal deficits or with the manner in which these deficits were financed? Based on the answers to these questions, several implications are drawn for the purposes of a macro-economic policy.

\section{METHODOLOGY}

The issue of crowding-out has been discussed at length in the literature. As Blejer and Khan (1985) note, one could argue with some justification that crowdingout may be a relatively common phenomenon in the developing world. While casual observation of the experiences of most developing countries would support this view, the mechanism or mechanisms through which such crowding-out occurs, if it does, are still being debated and there is no unanimity of views [Gupta (1992)].

\section{Previous Studies}

If budgetary deficits cause a displacement of private investment, a link should 
exist between budget deficits and interest rates, with rising interest rates leading to the crowding-out of private investment expenditures. As Burney and Yasmeen (1989) note, the empirical evidence on this point has been inconclusive. For example, they cite Cebula (1988); Deleuw and Holloway (1985); Hoelscher (1986) and Khan (1986) as having found evidence linking deficits to higher interest rates. On the other hand, Dewald (1983); Dwyer (1982); Evans (1987); Hoelscher (1983); Makin (1983); Mascaro and Meltzer (1983); McMillan (1986); Motley (1983) and Plosser (1982) found that deficits do not have a significant impact on interest rates. It should be noted, however, that all these studies focus almost exclusively on conditions in the developed countries.

Yet, several studies have attempted to identify the existence of crowding-out in the Pakistani context. In a recent study, Ahmad (1994) tests for this phenomenon over the 1970-1991 period. He also examines the hypothesis that the real interest rates are adversely influenced by the expected rate of inflation. Pakistan has experienced a host of structural changes during this period, especially in the financial sector. For example, a partial interest-free banking system was introduced in 1981. Pakistan also announced a policy of delinking the Pakistan rupee from the U.S. dollar and dropped a floating exchange rate system in 1981. This led to a sharp depreciation of the Pakistani currency and subsequently increased workers' remittances at an unprecedented rate.

After testing an IS-LM model, with interest rates related to real government spending, real government budget deficits, real money stock, and the expected rate of inflation, he finds that none of the explanatory variables exert a significant influence on the nominal rate of interest. The real rate of interest is adversely affected by the expected rate of inflation. From this he concludes that there is no support to the crowding-out hypothesis. This suggests that monetary and fiscal policies have no impact on interest rates and, therefore, stabilisation policies can be used in Pakistan (within reasonable limits) without worrying about their adverse effect on economic growth.

In contrast, Burney and Yasmeen's (1989) study focuses on possible budgetary links with interest rates. Their findings (p. 976) suggest that the overall government budget deficit in Pakistan does not have any significant impact on the nominal interest rates. However, when assumed that people can predict the future rate of inflation accurately, the overall deficit is found to have a significant impact on the nominal interest rate. Although they do not directly examine the impact on private investment, it is noted that there may be an inverse relationship between investment and nominal interest rates. If this is the case, their results suggest that an increase in the overall deficit is likely to crowd out private investment expenditure in Pakistan.

However, in the case of Pakistan, there is ample reason to believe that the 
usual crowding mechanisms involving rising interest rates (stemming from increased public domestic borrowing) are a minor factor in suppressing private investment as compared to credit rationing [Kemal (1991)] in an environment of financial repression. Khan (1988), for instance, has convincingly identified the presence of financial repression in the country's capital markets.

Similarly, Khan, Hasan and Malik (1992) find that the real interest rate exerted a positive and significant effect on the national savings rate. A one-percent increase in the real interest rate is likely to increase the savings rate by 0.07 percent. They conclude that this positive and significant effect of the real interest rate on the savings rate confirms the existence of financial repression in Pakistan.

Because the interest rate mechanism does not play nearly as active an allocative role in Pakistan and many other developing countries, the mechanisms responsible for possible crowding-out are not as well-established. Still, one could argue with some justification that, in view of the significant share of the public sector in total capital formation, the degree and magnitude of the administrative controls over the financial system, and the limited access to international capital markets by private borrowers, the government would still exercise a relatively strong influence over private investment.

The absence of a flexible interest rate mechanism means that the reduced form-type equations are more applicable for estimating possible crowding-out. Here crowding out can be broadly defined to include both financial and real crowding-out [Blejer and Khan (1985)].

\section{Financial Crowding-out}

Financial crowding-out stemming from fiscal deficits can be examined within the framework of one of three macroeconomic theories: (a) conventional crowdingout, (b) Keynesian crowding-out, as FitzGerald $(1979,1980,1987)$ calls it, and (c) the monetary approach to the balance of payments [Khan and Iqbal (1991)]. Let us have a description of these first.

1. Conventional Crowding-out occurs when the deficit is financed by selling bonds. The price of bonds is bid down (due to oversupply) which is equivalent to an increase in interest rates. The higher interest rates cause investment to decline or to be "crowded out" as a result of the higher deficit. Neither the savings nor the external balance is affected, since these depend on income and relative price levels, respectively.

2. The Monetary Approach examines the case where the deficit is monetised, creating an excess supply of money. Since interest rates are (for most smaller countries) determined internationally, savings and invest- 
ment are unchanged. Thus, there is either a capital outflow or an increase in imports-the full effect of the deficit is felt by the worsening of the external balance (B).

3. Keynesian Crowding-out assumes that any increase in the deficit is paid for through the increases in private savings. This is the same as a decrease in or the "crowding-out" of private consumption.

While seemingly straight-forward, when applied to developing countries, these theories have led to conflicting findings [Looney and Frederiksen (1987)]. For example, FitzGerald $(1979,1980)$ found that public deficits displaced or crowded out private consumption in Mexico. In this context, private savings increased to finance the deficit. Furthermore, the increase in savings came at the expense of private consumption rather than private investment. This finding suggests that under certain circumstances the fiscal deficit may actually mobilise savings for increased levels of investment, and thus growth. However, in their examination of Mexico, Looney and Frederiksen found a more Keynesian result: increases in the deficit were accompanied by increases in consumption. In addition, private investment was affected adversely by inflation (in turn probably stemming from government deficits).

Several studies have examined these issues in Pakistan. Bilquees (1989), for example, examines the relevance of the monetary approach to the balance of payments and suggested that the theory's strong assumptions concerning homogeneity and openness make its relevance questionable for Pakistan. Consistent with this, her empirical study finds that the monetary approach to the balance of payments fails to explain the flows of foreign reserves in Pakistan (and India), where monetary policy is restrictive and the foreign exchange and capital markets are controlled [Bilquees (1989), p. 202].

On the other hand, Khan and Iqbal (1991) find no evidence of either conventional or Keynesian crowding-out effects. Instead, they find that deterioration of the fiscal deficit has been worsening the current account balance, a finding that is in line with the monetary approach to the balance of payments.

In addition, their findings suggest that increases in the fiscal deficit have reduced private savings and, therefore, the investment and growth in Pakistan. Besides the existence of financial repression (low or negative real interest rates) and the lack of financial development (few financial institutions and the availability of few financial instruments), the fiscal deficit appears to be an important factor in accounting for such low savings. In short, their findings suggest that government savings are a substitute for private savings.

Khan and Iqbal's findings also imply a positive association between the price levels and private consumption, hence confirming the dominance of income effects. 
Since the increase in price level increases private consumption, it must reduce private savings and private investment.

In other studies, Haque and Montiel $(1991,1993)$ note that the macroeconomic consequences of fiscal deficits in Pakistan have apparently been quite different from those in other developing countries experiencing deficits of a comparable magnitude. Specifically, Pakistan has experienced neither hyper-inflation nor debtrescheduling. As measured by the official figures, growth has remained quite strong through the last two decades, inflation has not been high and the current account deficit has averaged to about $2 \frac{1}{2}$ percent of the GNP, largely remaining capable of being financed and not posing debt-servicing problems for the country. They argue that, to some extent, growth has itself accounted for this, as the associated expansion of the base for both conventional taxes and seigniorage has made it possible to finance "equilibrium" deficits that are significantly larger than would have been possible to finance in a slow-growth economy.

They warn, nevertheless, that since the early Eighties fiscal deficits have been financed by recourse to domestic non-bank borrowing, resulting in the increasing ratios of domestic public debt to the GNP and to the rising interest rates on such debt. Their model simulations suggest that while relying on this source of finance may have mitigated the inflationary consequences of the deficits, this has been done at the expense of some crowding-out of private investment and has, thus, implied a slower growth than would otherwise have been observed. Controlling the deficit over this period would have contributed to more favourable macroeconomic outcomes-at least with respect to growth and the external accounts-but not if the deficit reduction had been brought about in the manner commonly relied upon both in Pakistan and elsewhere-i.e., by reducing public investment.

\section{Real Crowding-out}

In addition to the financial factors noted above, private investment may have experienced real crowding-out. This occurs if government expenditures preempt scarce physical resources that would otherwise be available to the private sector.

As with financial crowding-out, however, the results of studies testing for real crowding-out have been mixed [Galbis (1979); Sundararajan and Thakur (1980); Wai and Wong (1982) and Looney (1992b)]. No doubt a complicating factor here stems from the fact that government expenditures can cause real "crowding-in" as well as real "crowding-out". As Noman (1991) observes, recent research such as that by Taylor (1988) has emphasised that private investment and public expenditures can be not only substitutes but also complements. Thus, certain public investments, e.g., on infrastructure, can "crowd in" à la Hirschman rather than crowd out private investment. He warns, however, that "ultimately [though] unsustainably large fiscal deficits, even if they are not crowding out the private sector for extended 
periods, force adjustment and if that is excessively delayed lead to a macroeconomic crisis" (p. 783).

Clearly, a case can be made that some form of crowding-out of private investment has occurred in Pakistan. The real issue seems to come down to the manner in which the crowding-out has taken place. To pin down these mechanisms, additional analysis needs to be undertaken:

1. In the studies noted above, the direction of causation has implicitly been assumed to go from government deficits to expanded domestic borrowing to interest rate increases and/or credit rationing and, ultimately, reduced private investment. One could just as easily argue that increased levels of private investment have placed pressure on the government to expand facilities, especially in energy. The government, wishing to aid private investment while simultaneously lacking adequate funding for major infrastructural programmes, may first grant the private sector various forms of relief such as tax holidays followed by modest increases in public investment. The outcome of this process would be expanded deficits, but not necessarily the crowding-out of private investment in the classical sense. The causation issue must be addressed before any definitive conclusion concerning crowding-out can be reached.

2. As a related issue, the timing of these impacts needs to be identified. Many effects associated with government deficits are likely to have a delayed impact on private investment decisions. Again, because the timing of these effects has not been spelled out, the patterns of causation are unclear. Gupta (1992) does make an attempt to identify the relevant lag structure, but these are arrived at in a somewhat arbitrary manner.

3. If we assume that interest rate effects are only one factor associated with the government deficit as it pertains to private investment, the theory of crowding-out becomes unclear as to the relevant form of the budgetary deficit. If the interest rate mechanism is not perfect, are private investors more concerned or affected (through perhaps credit rationing) by the actual deficit, some sort of expected deficit, unanticipated changes in the deficit, or even deviations in the deficit from some longer-run budgetary trend?

4. The environment in which deficits exist needs to be identified. Obviously, if deficits stem largely from increased government consumption or defense, their negative impact on private investment will be the greater than if they had stemmed simply from increased infrastructural investment.

5. The financing of the public sector deficit and government capital forma- 
tion needs to be examined in detail. Have the deficits been associated with government investment or consumption? How have the deficits been financed as between domestic and foreign borrowing? Do the impacts of domestic versus foreign borrowing vary with regard to their effect on private industrial investors?

6. One reason for these inconclusive results is due to the failure to separate out the real from financial crowding-out. In this regard, Blejer and Khan $(1984,1985)$ have argued that public investment involves both the development of infrastructure, which would likely be complementary with private investment, and other types of non-infrastructural investment that competes with private investment either through absorbing limited physical resources or thorough the production of marketable output. Taken together, these effects of the infrastructural and non-infrastructural components can offset each other, thereby yielding the impression that the impact of total government investment on the level of private investment is weak or insignificant. Their work has shown that once the two aspects of public investment are recognised, and a distinction made along functional lines involving infrastructural and non-infrastructural investment, much stronger statements can be made on the role of governmental investment in private capital formation.

\section{The Issue of Causation}

As noted, a major issue in the analysis of the role of government deficits in Pakistan's post-1971 development centres around the direction of causation: do deficits affect private sector investment in manufacturing as suggested by the crowding-out school or do deficits simply respond to the needs created by an expanding economy?

It follows that before drawing any definitive conclusions as to the impact of the public sector deficit, one must satisfactorily address the issue of causation. Fortunately, several statistical tests using regression analysis for this purpose are gaining wider acceptance. The original and most widely used causality test was developed by Granger (1969). According to this test, deficits (DEF) affect (say) the growth of private sector investment in manufacturing (PIM) if this series can be predicted more accurately by past values of deficits than by past (investment) growth patterns. To be certain that causality runs from deficits to PIM, past values of the public deficit must also be more accurate than past values of private investment at predicting increases in the deficit.

The results of Granger causality tests depend critically on the choice of lag length. If the chosen lag length is less than the true lag length, the omission of rele- 
vant lags can cause bias. If the chosen lag is greater than the true lag length, the inclusion of irrelevant lags causes the estimates to be inefficient. While it is possible to choose lag lengths based on preliminary partial auto-correlation methods, there is no a priori reason to assume lag lengths equal for all types of deficits.

\section{The Hsaio Procedure}

To overcome the difficulties noted above, Hsaio (1981) developed a systematic method for assigning lags. This method combines the Granger Causality and Akaike's final prediction error (FPE), the (asymptotic) mean square prediction error, to find the optimum lag for each variable. In a paper examining the problems encountered in choosing lag lengths, Thornton and Batten (1985) found Hsaio's method to be superior to both arbitrary lag length selection and several other systematic procedures for determining lag length.

Depending on the value of the final prediction errors [Looney (1994)], four cases are possible. (a) Fiscal Policies (Deficits, Borrowing, Expenditures) cause Private Investment when the prediction error for private investment decreases as the fiscal action is included in the growth equation. In addition, when private investment is added to the fiscal equation, the final prediction error should increase. (b) Private Investment causes a Fiscal Response when the prediction error for private investment increases as fiscal actions are added to the regression equation for private investment, and is reduced when private investment is added to the fiscal regression equation. (c) Feedback occurs when the final prediction error decreases as a fiscal policy is added to the private investment equation, and the final prediction error decreases when private investment is added to the fiscal equation. And (d) No Relationship exists when the final prediction error increases both as fiscal policies are added to the private investment equation and as private investment is added to the fiscal equation.

\section{Operational Procedures}

The data used to carry out the causation tests was derived from the World Bank $(1984,1991,1992,1993)$ data figures: the Gross Domestic Product and the GDP price deflator is from the IMF publication, International Financial Statistics. All variables are in logarithmic ${ }^{1}$ form, were deflated by the GDP deflator, and are in constant 1985 prices.

To determine the robustness of our findings (and whether the results were

${ }^{1}$ Before running the regressions, unit root tests were carried out to check for stationarity-cf. Doornik and Hendry (1994). The results of these tests indicated that the variables included in the equations were stationary. A similar finding has been reported in Sakr (1993). 
sensitive to the definition of key variables), various measures of the deficit were examined. These included the actual (or realised) deficit, the expected deficit (the predicted value obtained by regressing each year's deficit on its value for the previous year), and the unexpected deficit (the difference between each year's actual deficit and that anticipated based on past patterns). A priori we might expect that unanticipated increases in the fiscal deficits or in domestic borrowing would have a stronger effect on private investment. Presumably, unanticipated increases in these variables signify more of an emergency borrowing situation, thus making it more difficult for the private sector to realise its borrowing needs.

Relationships were considered valid if they were statistically significant at the ninety-five percent level of confidence. That is, if ninety-five percent of the time we could conclude that they had not occurred purely by chance, we considered them statistically significant.

As noted above, there is no theoretical reason to believe that fiscal deficits and private investment in manufacturing have a set lag relationship-that is, they influence one another over a fixed period. To find the optimal adjustment period of impact, lag structures of upto six years were estimated. ${ }^{2}$ The lag structure with the highest level of statistical significance was the one chosen as depicting best the relationship under consideration (the optimal lag reported in Tables 1 through 3 ).

Besides the financial variables (fiscal deficits, public sector borrowing) traditionally used in crowding-out analysis, several types of government expenditure were also examined. Infrastructure investment was defined as general government investment (consisting of federal, provincial, and local investment). Non-infrastructural public investment consists largely of investment in public enterprises and was defined as total public investment minus general (infrastructural) investment.

Ceteris paribus, infrastructure investment should have a positive ("crowd in") effect on private investment since it is most likely to reduce the costs of private sector manufacturing and thus to stimulate capital formation in that sector. On the other hand, non-infrastructural investment is assumed, ceteris paribus, to result in "real" crowding out of private investment.

As a basis of comparison, government consumption (and in several cases defense expenditure) was also included in the analysis. Since this type of expenditure is not likely to compete with the private sector for resources, real crowding out was assumed not to be a factor affecting private investment. On the other hand, the manner in which government consumption was financed might cause either financial crowding out or a Keynesian demand-induced expansion in private investment.

${ }^{2}$ A set of detailed statistical results are available from the author upon request. These include the final prediction effort, Durban-Watson statistic, and the adjusted $r^{2}$ statistic. 


\section{Table 1}

Pakistan: Causal Patterns:

Private Investment in Large-scale Manufacturing

\begin{tabular}{cccc}
\hline \multirow{2}{*}{ Relationship } & $\begin{array}{c}\text { Direction of } \\
\text { Causation }\end{array}$ & $\begin{array}{c}\text { Optimal } \\
\text { Lag (Years) }\end{array}$ & $\begin{array}{c}\text { Relative } \\
\text { Strength }\end{array}$ \\
\hline
\end{tabular}

Private Investment/Financial Policies

(1) Realised Fiscal Deficit

(2) Realised Public Domestic Borrowing

(3) Realised Public Foreign Borrowing

(4) Unexpected Fiscal Deficit

(5) Unexpected Domestic Borrowing

(6) Unexpected Public Foreign Borrowing

$\begin{array}{lll}\text { Feedback } & 1,-2,+ & \mathrm{w}, \mathrm{w} \\ \text { Feedback } & 1,-2,+ & \mathrm{m}, \mathrm{w} \\ \text { No Relationship } & & \\ \text { Feedback } & 4,-1,+ & \mathrm{m}, \mathrm{m} \\ \text { Feedback } & 1,-1,+ & \mathrm{m}, \mathrm{w}\end{array}$

No Relationship

\section{Private Investment/Expenditure Policies}

(7) Realised Public Infrastructure Invest.

(8) Realised Public Non-infst. Investment

(9) Realised Public Consumption

(10) Unexpected Infrastructure Invest.

$\begin{array}{lcc}\text { Private } \rightarrow \text { Public } & 1+ & \text { s } \\ \text { Private } \rightarrow \text { Public } & 4+ & \text { w } \\ \text { Public } \rightarrow \text { Private } & 4+ & \text { s } \\ \text { Private } \rightarrow \text { Public } & 2+ & \text { w } \\ \text { Feedback } & 4,-2,+ & \text { s,w } \\ \text { Public } \rightarrow \text { Private } & 3+ & \text { s }\end{array}$

(11) Unexpected Non-infrastructural Invest.

(12) Unexpected Public Consumption

\section{Unexpected Private Investment/Fiscal Policies}

(13) Unexpected Fiscal Deficit

(14) Unexpected Domestic Borrowing

(15) Unexpected Public Foreign Borrowing

(16) Unexpected Infrastructure Invest.

(17) Unexpected Non-infrastructural Invest.

(18) Unexpected Public Consumption
No Relationship

Public $\rightarrow$ Private

$1(-)$

$\mathbf{W}$

No Relationship

Private $\rightarrow$ Public

$4+$

m

Feedback

$4,-1,-$

$\mathbf{S}, \mathbf{w}$

Notes: See text for a description of the estimation methods. The dominant pattem is that with the lowest final prediction error. All variables are estimated in logarithmic form. The signs $(+,-)$ represent the direction of the impact. In the case of feedback, the first term is the impact of fiscal policy on private investment; the second is the impact of private investment on fiscal policy. Strength assessment, (w) week, (m) moderate, and (s) strong, is made on the basis of the improvement in $r^{2}$ and the size of the standardised regression coefficient. 
Table 2

Pakistan: Causal Patterns:

Private Investment in Small-scale Manufacturing

\begin{tabular}{cccc}
\hline \multirow{2}{*}{ Relationship } & $\begin{array}{c}\text { Direction of } \\
\text { Causation }\end{array}$ & Optimal & Relative \\
Lag (Years) & Strength \\
\hline
\end{tabular}

Private Investment/Financial Policies

(1) Realised Fiscal Deficit

Private $\rightarrow$ Public

2

$\mathbf{m}$

(2) Realised Public Domestic Borrowing

Feedback

$3,+1,+$

$\mathbf{m}, \mathbf{m}$

(3) Realised Public Foreign Borrowing

No Relationship

(4) Unexpected Fiscal Deficit

Private $\rightarrow$

$2+$

$\mathbf{w}$

(5) Unexpected Domestic Borrowing

Feedback

$4,+1,+$

m,w

(6) Unexpected Public Foreign Borrowing

No Relationship

\section{Private Investment/Expenditure Policies}

(7) Realised Public Infrastructure Invest.

(8) Realised Public Non-infst. Investment

(9) Realised Public Consumption

(10) Unexpected Infrastructure Invest.

(11) Unexpected Non-infrastructural Invest.

(12) Unexpected Public Consumption

Private $\rightarrow$ Public

$1+$

$\mathbf{w}$

Feedback

$1,+1,+$

w,w

Public $\rightarrow$ Private

$3+$

w

Feedback

$3,-1,+$

$\mathbf{w}, \mathbf{w}$

No Relationship

Public $\rightarrow$ Private

$$
1(-)
$$

$\mathbf{w}$

Unexpected Private Investment/Fiscal Policies

(13) Unexpected Fiscal Deficit

(14) Unexpected Domestic Borrowing

(15) Unexpected Public Foreign Borrowing

(16) Unexpected Infrastructure Invest.

(17) Unexpected Non-infrastructural Invest.

(18) Unexpected Public Consumption
Private $\rightarrow$ Public

Feedback

No Relationship

No Relationship

Private $\rightarrow$ Public

Public $\rightarrow$ Private
$1(-)$

m

$2,+1,-$

$\mathbf{w}, \mathbf{m}$

Notes: See text for a description of the estimation methods. The dominant pattem is that with the lowest final prediction error. All variables are estimated in logarithmic form. The signs $(+,-)$ represent the direction of impact. In the case of feedback, the first term is the impact of fiscal policy on private investment; the second is the impact of private investment on fiscal policy. Strength assessment, (w) week, (m) moderate, and (s) strong, is made on the basis of the improvement in $r^{2}$ and the size of the standardised regression coefficient. 
Table 3

Pakistan: Causal Patterns:

Private Non-manufacturing Investment

\begin{tabular}{cccc}
\hline Relationship & $\begin{array}{c}\text { Direction of } \\
\text { Causation }\end{array}$ & Optimal & Relative \\
Lag (Years) & Strength \\
\hline
\end{tabular}

Private Investment/Financial Policies

(1) Realised Fiscal Deficit

(2) Realised Public Domestic Borrowing

(3) Realised Public Foreign Borrowing

(4) Unexpected Fiscal Deficit

(5) Unexpected Domestic Borrowing

(6) Unexpected Public Foreign Borrowing

Private Investment/Expenditure Policies

(7) Realised Public Infrastructure Invest.

(8) Realised Public Non-infst. Investment

(9) Realised Public Consumption

(10) Unexpected Infrastructure Invest.

(11) Unexpected Non-infrastructural Invest.

(12) Unexpected Public Consumption

$\begin{array}{lll}\text { Feedback } & 3,+1,+ & \text { m,w } \\ \text { Feedback } & 2,+1,+ & \text { w,w }\end{array}$

No Relationship

Feedback

$2,+1,+$

$\mathbf{s , m}$

Feedback

$2,+1,+$

$\mathbf{m}, \mathbf{w}$

$\begin{array}{lcc}\text { Feedback } & 4,+4,+ & \text { w,m } \\ \text { Feedback } & 1,+2,+ & \text { w,w } \\ \text { Feedback } & 1,+2,+ & \text { w,w } \\ \text { Private } \rightarrow \text { Public } & 1+ & \text { w } \\ \text { Private } \rightarrow \text { Private } & 2+ & \text { w }\end{array}$

No Relationship

\section{Unexpected Private Investment/Fiscal Policies}

(13) Unexpected Fiscal Deficit

(14) Unexpected Domestic Borrowing

(15) Unexpected Public Foreign Borrowing

(16) Unexpected Infrastructure Invest.

(17) Unexpected Non-infrastructural Invest.

(18) Unexpected Public Consumption
Public $\rightarrow$ Private

$2+$

$\mathbf{W}$

No Relationship

No Relationship

No Relationship

Feedback

$1,+1,-$

$\mathbf{w}, \mathbf{m}$

Notes: See text for a description of the estimation methods. The dominant pattern is that with the lowest final prediction error. All variables are estimated in logarithmic form. The signs $(+,-)$ represent the direction of impact. In the case of feedback, the first term is the impact of fiscal policy on private investment; the second is the impact of private investment on fiscal policy. Strength assessment, $(w)$ week, $(m)$ moderate, and (s) strong, is made on the-basis of the improvement in $r^{2}$ and the size of the standardised regression coefficient. 
To sum up, the expected impact of the governmental financial and expenditure policies on private investment in manufacturing is as follows:

Fiscal Policy

\section{Financial}

Fiscal Deficits

Domestic Borrowing

Foreign Borrowing

\section{Expenditure}

Infrastructure

Non-infrastructure

Consumption
Expected Impact

$\begin{array}{ll}- & \begin{array}{l}\text { financial crowding out } \\ \text { financial crowding out } \\ \text { increased foreign exchange }\end{array} \\ + & \text { real crowding in } \\ - & \text { real crowding out } \\ ? & \text { net outcome real/financial }\end{array}$

Mechanism

Using this framework:

1. We examined both the financial and real impacts of fiscal policy on private investment in manufacturing.

2. Because we would expect large manufacturing units to be more dependent on outside financing, separate tests were carried out for large and small firms.

3. As a basis of comparison, similar tests were performed on: (1) total private non-manufacturing investment, (2) private investment in housing, and (3) private investment in transport/communications.

4. To assess whether specific public expenditures were financed in a particular way (e.g., general deficit or internal/external borrowing), we examined the links between the government's expenditures and its fiscal accounts.

\section{RESULTS}

This analysis produced a number of interesting findings (Tables 1-3). First, here are the findings regarding the impact and interaction of the government's financial/expenditure policies on private investment in large-scale manufacturing (Table 1):

1. Consistent with the crowding-out hypothesis, the overall impact (Equation 1) of the actual (realised) deficit on private investment in manufacturing was negative. This effect, however, was rather weak and on average occurred with a lag of one year. In turn, increases in private 
investment produced a weak response expansion in the deficit. On average, this effect occurred over a two-year period.

2. Reinforcing the crowding-out hypothesis, the results obtained using public borrowing in the domestic capital markets (Equation 2) also produced feedback patterns showing the impact of borrowing on private investment as negative. This negative effect on private investment was stronger than that produced by the fiscal deficits.

3. Also consistent with the crowding-out hypothesis was the pattern associated with public borrowing in foreign markets (Equation 3). Borrowing in these markets had no impact on private investment, that is, government borrowing in foreign markets did not come at the expense of private investment in large-scale manufacturing.

4. As expected, unanticipated fiscal deficits and public borrowing in the domestic capital markets was more detrimental (Equations 4 and 5) to private investment than the effects produced by the actual/realised deficits and borrowings. Again, the relationship between fiscal policy and private investment was a feedback pattern, with increased private investment stimulating further fiscal deficits and public borrowing in the domestic capital markets.

5. As with realised foreign borrowing, unanticipated borrowing in external markets had no statistically significant impact on private investment in large-scale manufacturing.

The pattern of government expenditures and private investment expenditures on private investment in large-scale manufacturing also produced several interesting insights.

1. Both the infrastructural and non-infrastructural components of public investment responded (Table 1, Equations 7 and 8 ) to the needs produced by expanded private investment, that is, private investment in large-scale manufacturing induced a follow-on increase in government investment. Infrastructure was the more responsive component of government investment, with private investment inducing a strong and rapid (optimal lag of one year) governmental response.

2. Increased government consumption provides (Equations 9 and 12) a fairly strong stimulus to private investment in large-scale manufacturing. Because of its strength in both the realised and the unanticipated forms, consumption probably stimulates private investment through a Keynesian demand linkage mechanism.

3. The link between private investment in large-scale manufacturing and 
unexpected public investment varied by type of investment. Unexpected infrastructure investment (Equation 10) appears to be a response to the needs of the private sector. No doubt, this expansion in infrastructural facilities tends to be the largest during periods of acceleration in private investment.

4. On the other hand, non-infrastructural investment appears to crowd out a certain amount of private investment in large-scale manufacturing (Equation 11). Also, a feedback mechanism occurs here, whereby increases in private investment also encourage a further expansion of non-infrastructural investment.

As noted above, tests were also undertaken for unanticipated private investment in large-scale manufacturing. Our logic here was that this measure of private investment might be more sensitive to sudden shifts in financial conditions than the level of private investment. This assumption, however, was not completely borne out by the tests:

1. No statistically significant patterns exist between unexpected private investment (Equation 13) in large-scale manufacturing and unanticipated fiscal deficits.

2. Unexpected increases in domestic borrowing (Equation 14) did, however, crowd out a certain amount of private investment, although this effect was rather weak.

3. On the other hand, the patterns between unexpected government investment in infrastructure and private investment were quite strong, with private investment again inducing a follow-on amount of infrastructure expansion.

4. Links with non-infrastructural investment were of a feedback-type increase in non-infrastructural investment strongly suppressing private investment. In turn, unexpected expansions in private investment lowered the future increases in non-infrastructural investment. This final effect, however, was relatively weak.

5. Apparently, the demand increases associated with unexpected increases in public consumption (Equation 18) are not considered significant enough to warrant a response by private large-scale manufacturing investors.

For the purposes of this study, the patterns associated with private investment in small-scale manufacturing (Table 2) were in sharp contrast to those found to characterise large-scale manufacturing. Again, looking mostly for evidence of the 
crowding out of private investment, the following observations are to be made.

1. In contrast to the negative impact on private investment in large-scale manufacturing produced by fiscal deficits, private investment in smallscale industries increased with the size of the deficit (Table 2, Equation 2). This pattern also characterised unexpected domestic borrowing (Equation 5).

2. In addition, the fiscal deficit appears to have almost no impact on investment in small-scale manufacturing. Instead, increases in this type of investment encourage follow-on public expenditures (Equations 7 and 8) which, in turn, cause the government to accelerate expenditures relative to revenues (Equations 1 and 4).

3. A final contrast occurs with respect to unexpected public consumption. Instead of stimulating further private investment, this form of public expenditure suppresses (Equation 12) further private investment.

4. Finally, the results using unexpected private investment in small-scale manufacturing produced little in the way of firm evidence for crowdingout, either of the financial or real type. In fact, unanticipated increases in domestic borrowing were associated with further increases in private investment (Equation 14).

Private investment in non-manufacturing activities produced another distinctive pattern (Table 3):

1. Overall evidence exists of crowding-out, financial or real. The dominant pattern is one of feedbacks both between public sector financial and expenditure activities and private investment (Equations 1, 2, 4, 5, 7 and 8).

2. Overall, the impacts of these feedbacks are the strongest in the direction of public to private. The one exception here is the relatively strong impact of increased private investment on government infrastructural investment (Equation 7).

3. The only negative impact is between unexpected increases in private investment and unexpected increases in non-infrastructural investment. However, from these results alone it is impossible to identify the source of this pattern, i.e., whether, for example, the private sector was able to crowd out the public sector by outbidding it for resources.

\section{POLICY IMPLICATIONS}

These findings suggest that crowding-out may be largely confined to one 
(albeit a very important) area of investment, private investment in large-scale manufacturing. Here crowding-out appears to be largely related to increased fiscal deficits and associated domestic borrowing. However, unanticipated increases in public investment in non-infrastructural activities may cause some real crowding-out.

As is often found in the industrial countries, recent research on public expenditures in developing countries suggests that the potentially beneficial effects of public investment are often offset by adverse developments in financial markets-the so-called crowding-out effect. Similarly, increased public sector investment may preempt resources that might otherwise be available at reasonable prices for private investment-i.e., real crowding-out. Our main assumption in designing this study was that for the financial crowding-out hypothesis to be valid for Pakistan, a pattern should occur whereby increased public expenditures expand the size of the fiscal deficit. In turn, the enlarged deficit is financed through additional domestic borrowing rather than alternative sources of funding (taxes, foreign borrowing). Here the assumption was that real crowding-out might be inferred if two conditions were present: (a) causation was from public investment to private investment and its impact was negative, and (b) causation was not from increased public investment to increased government borrowing in the domestic markets.

The causality tests suggest that expanded public investment in infrastructure has not played an important role in stimulating private investment in industry. If anything, the results suggest that it is private investment that has stimulated a follow-on expansion in infrastructure. Instead of crowding in (i. e., a positive feedback effect) additional private investment, however, infrastructure investment appears to have led to larger dificits, and domestic borrowing. In turn, these financial developments have slowed down the flows of private capital into the important large-scale manufacturing sector.

\section{CONCLUDING REMARKS}

To sum up, financial crowding-out of private investment in large-scale manufacturing is a distinct possibility, but it may not be a simple, straightforward process. The results obtained above also suggest that private investment in largescale manufacturing has suffered from real crowding-out associated with the government's non-infrastructural investment programme. Finally, it should be noted that neither financial nor real crowding-out seems to occur in other areas of private investment. Clearly, further research should be undertaken to determine why the large-scale manufacturing sector is unique in this regard.

\section{REFERENCES}

Ahmad, M. (1994) The Effects of Government Budget Deficits on Interest Rates: A 
Case Study of a Small Open Economy. Economia Internazionale 47:1 1-6. Bilquees, Faiz (1989) Monetary Approach to Balance of Payments: The Evidence on Reserve Flow from Pakistan. The Pakistan Development Review 28:3 195-206.

Blejer, Mario I., and M. S. Khan (1984) Government Policy and Private Investment in Developing Countries. IMF Staff Papers 31:2 379-403.

Blejer, Mario I., and Mohsin S. Khan (1985) Public Investment and Crowding-out in the Caribbean Basin Countries. In Michael Connolly and John McDermott (eds) The Economics of the Caribbean Basin. New York: Praeger Publishers.

Burney, Nadeem A., and Attiya Yasmeen (1989) Government Budget Deficits and Interest Rates: An Empirical Analysis for Pakistan. The Pakistan Development Review 28:4 971-980.

Cebula, J. R. (1988) Federal Budget Deficit and Interest Rates: An Empirical Analysis for the United States. Public Finance 43:3 337-47.

Deleuw, F., and T. Holloway (1985) The Measurement and Significance of Cyclically Adjusted Federal Budget and Deficits. Journal of Money, Credit and Banking 17:2 20-29.

Dewald, W. G. (1983) Federal Deficits and Real Interest Rates: Theory and Evidence. Federal Reserve Bank of Atlanta Economic Review 68: 20-29.

Doornik, Jurgen A., and David F. Hendry (1994) PcGive 8.0. London: Thompson Publishing.

Dwyer, G. (1982) Inflation and Government Deficits. Economic Inquiry 20:3 315-29.

Evans, P. (1987) Interest Rates and Expected Future Deficits in the United States. Journal of Political Economy 95:1 34-55.

FitzGerald, E. V. K. (1979) The Fiscal Deficit and Development Finance: A Note on the Accumulation Balance in Mexico. Cambridge: Cambridge University Centre of Latin American Studies. (Working Paper No. 35.)

FitzGerald, E. V. K. (1980) A Note of Capital Accumulation in Mexico: The Budget Deficit and Investment Finance. Development and Change 11:3 391-417.

FitzGerald, E. V. K. (1987) Looney and Frederiksen on Mexican Fiscal Policy: A Reply. World Development 15:3 405-406.

Galbis, V. (1979) Money Investment and Growth in Latin America, 1961-1973. Economic Development and Cultural Change 27:3 423-43.

Gupta, Kanhaya L. (1992) Ricardian Equivalence and Crowding-out in Asia. Applied Economics 24:1 19-25.

Granger, C. W. J. (1969) Investigating Causal Relations by Econometric Models and Cross-Spectral Methods. Econometrica 36: 424-438.

Haque, Nadeem U., and Peter Montiel (1991) The Macroeconomics of Public Sector Deficits: The Case of Pakistan. Country Economics Department, Research and 
External Affairs. Washington, D. C.: The World Bank. (Working Papers WPS 673.)

Haque, Nadeem U., and Peter Montiel (1993) Fiscal Adjustment in Pakistan: Some Simulation Results. IMF Staff Papers 40:2 471-482.

Hirschman, H. O. (1958) The Strategy of Economic Development. New Haven, CT: Yale University Press.

Hoelscher, G. (1983) Federal Borrowing and Short-term Interest Rates. Southern Economic Journal 50:2 319-33.

Hoelscher, G. (1986) New Evidence on Deficits and Interest Rates. Journal of Money, Credit and Banking 18:1 1-17.

Hsiao, C. (1981) Autoregressive Modelling and Money-income Causality Detection. Journal of Monetary Economics 8: 85-106.

International Monetary Fund (Various Issues) International Financial Statistics Yearbook. Washington, D. C.: International Monetary Fund.

Kemal, A. R. (1991) Options for Financing the Budgetary Deficit, Money Supply, and Growth of the Banking Sector. The Pakistan Development Review 30:4 769-784.

Khan, Ashfaque H. (1988) Financial Repression, Financial Development, and Structure of Savings in Pakistan. The Pakistan Development Review 27:4 701-711.

Khan, Ashfaque H., Lubna Hasan and Afia Malik (1992) Dependency Ratio, Foreign Capital Inflows, and the Rate of Savings in Pakistan. The Pakistan Development Review 31:4 843-856.

Khan, Ashfaque H., and Z. Iqbal (1991) Fiscal Deficit and Private Sector Activities in Pakistan. Economia Internazionale 44:2-3 182-183.

Khan, Z. H. (1986) Government Budget Deficits and Interest Rates: The Evidence Since 1971, Using Alternative Deficit Measures. Southern Economic Journal 50:2 1-17.

Looney, Robert E. (1992) Infrastructure and Private Sector Investment: The Case of

Pakistan's Transportation and Communications Sector, 1972-90. Rivista Intermazionale di Scienze Economiche e Commerciali 39:9 771-792.

Looney, Robert E. (1992a) Infrastructural Constraints on Transport and Communications: The Case of Pakistan. International Journal of Transport Economics 19:3 287-306.

Looney, Robert E. (1992b) Real or Illusory Growth in an Oil-based Economy: Government Expenditures and Private Sector Investment in Saudi Arabia. World Development 20:9 1367-1376.

Looney, Robert E. (1994) The Economic Consequences of Defense Expenditures in the Middle East. METU Studies in Development 21:1 89-112.

Looney, Robert E., and P. C. Frederiksen (1981) The Regional Impact of 
Infrastructure in Mexico. Regional Studies 15:4 285-296.

Looney, R. E., and P. C. Frederiksen (1987) Fiscal Policy in Mexico: The

FitzGerald Thesis Reexamined. World Development 15:3 399-405.

Looney, Robert E., and David Winterford (1992) The Role of Infrastructure in

Pakistan's Economic Development: 1972-1991. Pakistan Economic and Social Review 30:1 69-94.

Makin, J. H. (1983) Real Interest Money Surprises, Anticipated Inflation, and Fiscal Deficits. Review of Economics and Statistics 65:3 374-84.

Mascaro, A., and A. H. Meltzer (1983) Long and Short-term Interest Rates in a Risky World. Journal of Monetary Economics 10: 151-200.

McMillan, W. D. (1986) Federal Deficits and Short-term Interest Rates. Journal of Macroeconomics 8: 403-22.

Motley, B. Real (1983) Interest Rates, Money and Government Deficits. Federal Reserve Bank of San Francisco Economic Review 31-45.

Noman, Akbar (1991) Comments on "Options for Financing the Budgetary Deficit, Money, Supply, and Growth of the Banking Sector". The Pakistan Development Review 30:4 782-784.

Plosser, C. Z. (1982) Government Financing Decisions and Asset Returns. Journal of Monetary Economics 9:3 325-52.

Sakr, Khaled (1993) Determinants of Private Investment in Pakistan. Washington, D. C.: The International Monetary Fund. (Working Paper.)

Sundararajan, V., and S. Thakur (1980) Public Investment, Crowding-out, and Growth: A Dynamic Model Applied to India and Korea. IMF Staff Papers 27: 814-55.

Taylor, Lance (1988) Varieties of Stabilisation Experiences. Oxford: Clarendon Press.

Thornton, D. L., and D. S. Batten (1985) Lag-length Selection and Tests of Grander Causality between Money and Income. Journal of Money, Credit and Banking 12: 164-78.

Wai, U. Tun, and C. Wong (1982) Determinants of Private Investment in Developing Countries. Journal of Development Studies 19: 19-36.

World Bank (1984) Pakistan: Progress under the Sixth Plan. Washington, D. C.: The World Bank.

World Bank (1991) Pakistan: Current Economic Situation and Prospects-Report No. 9283-PAK. Washington, D. C.: The World Bank.

World Bank (1992) Pakistan: Current Economic Situation and Prospects-Report No. 10223-PAK. Washington, D. C.: The World Bank.

World Bank (1993) Pakistan: Country Economic Memorandum FY93: Progress under the Adjustment Programme-Report No. 11590-PAK. Washington, D. C.: The World Bank. 